DARIUSZ NOWOTNIK

Uniwersytet Pedagogiczny, Kraków, Polska

\title{
Imigracje zagraniczne na stale do Polski
}

\section{Permanent Foreign Immigrations into Poland}

Streszczenie: W pierwszych latach po wstąpieniu Polski do Unii Europejskiej, szczególne znaczenie miało zjawisko emigracji zarówno czasowej, jak i stałej z Polski do krajów Europy Zachodniej i Północnej o dużym natężeniu. Z biegiem lat ruch emigracyjny trochę osłabł na skutek światowego kryzysu gospodarczego przejawiającego się m.in. mniejszą liczbą miejsc pracy oraz zwolnieniami w krajach imigracyjnych pracowników o krótkim stażu pracy, czyli głównie imigrantów. Nie bez znaczenia był też fakt nieco mniejszego zapotrzebowania na pracę na rynkach zagranicznych, co było związane z tym, iż większość najbardziej zdeterminowanych Polaków wyjechała za granicę w pierwszych latach po przystąpieniu Polski do Unii Europejskiej.

Zwiększyło się natomiast natężenie imigracji na stałe do Polski. Wpływ na to mógł mieć duży udział Polaków w strukturze imigracji do Polski. Imigranci przyjeżdżający do Polski na stałe pochodzili przede wszystkim z Wielkiej Brytanii, Niemiec i Irlandii, czyli głównych krajów docelowych polskiej emigracji poakcesyjnej. Do Polski licznie przyjeżdżano również ze Stanów Zjednoczonych i Kanady, krajów, w których mieszka duża liczba ludności polskiego pochodzenia. Pewna część imigrantów pochodziła także z państw słabiej rozwiniętych, w tym głównie z Wietnamu i Ukrainy.

W artykule przedstawiono natężenie imigracji zagranicznej na stałe do Polski. Wskazano również pochodzenie imigrantów zagranicznych według wybranych krajów wcześniejszego zamieszkania. Dokonano charakterystyki imigrantów pod względem płci, wieku i stanu cywilnego. W pracy przedstawiono również rozmieszczenie przestrzenne imigrantów zagranicznych na stałe według gmin w Polsce w wybranych latach.

\begin{abstract}
In the first years after Poland's accession to the European Union, the phenomenon of both temporary and permanent emigration from Poland into West and North European countries proved particularly important, as the outflow was quite significant. In the following years, the migratory movement decreased owing to the impact of the world economic crisis, which manifested itself in a smaller number of available jobs, as well as layoffs. The latter were particularly visible in immigration countries, where they mostly affected employees fresh in their jobs - that is, mainly immigrants. What is more, the demand for jobs in foreign markets also decreased, as the majority of the most determined Poles had already moved abroad in the first years after Poland's accession to the European Union.
\end{abstract}


In contrast, permanent immigration into Poland grew in intensity. This may have been caused the significant share of Poles in the structure of permanent immigration into Poland. The immigrants arriving in Poland for a permanent stay frequently came from the United Kingdom, Germany and Ireland the main destination countries for Polish post-accession emigrants. The immigrants arriving from the United States and Canada were also numerous, as these countries have a high percentage of inhabitants with Polish ancestors. Some immigrants arrived also from the developing countries, mainly from Vietnam and Ukraine. Finally, repatriations of Poles, mainly from Kazakhstan, played a special role in the phenomenon.

The article presents the intensity of permanent foreign immigration into Poland in general. It also outlines the countries that immigrants come from, sorted by selected countries of origin. The immigrants have been classified by their sex, age and marital status. The work also includes an analysis of the spatial diversity of permanent immigrants from abroad by Polish municipality (gminas), in selected years.

Słowa kluczowe: imigracja, zróżnicowanie przestrzenne, osoby objęte ruchem wizowym, obcokrajowcy, zameldowania

Key words: immigration, spatial diversity, people covered by the visa movement, foreigners, registered residence

\section{WPROWADZENIE}

Pojęcie imigracji zagranicznych na stałe do Polski znajdowało się w ostatnich latach poza głównym nurtem badań naukowych. Wpływ na ten stan rzeczy miała znikoma jej rola w kształtowaniu salda migracji zagranicznych na stałe dla Polski. Liczba wyjazdów polskich emigrantów do krajów Europy Zachodniej zaczyna jednak maleć, a jednocześnie wzrasta liczba imigrantów przybywających do Polski. Jest to związane z nasycaniem się rynków pracy w najbogatszych krajach należących do Unii Europejskiej napływowymi pracownikami z państw biedniejszych oraz pogorszeniem sytuacji na lokalnych rynkach pracy w wyniku m.in. skutków światowego kryzysu gospodarczego (Kaczmarczyk, 2010). Chłonność tych rynków powoli zaczyna się wyczerpywać, przez co wzrasta konkurencja oraz maleją szanse na znalezienie zatrudnienia na dobrych warunkach ekonomicznych. Taka sytuacja najpierw wzmogła natężenie reemigracji do Polski (zwłaszcza w początkowym okresie światowego kryzysu gospodarczego), lecz nie było to zjawisko masowe (Iglicka, 2009). Innym ważnym powodem podjęcia decyzji o powrocie do kraju były względy rodzinne zarówno w ojczyźnie, jak i kraju przyjmującym (Grabowska-Lusińska, 2010). Pogorszenie się perspektyw na unijnych rynkach pracy wpłynęła też na niższy poziom emigracji z Polski do tych krajów. Obecnie Polska zaliczana jest do tzw. krajów transformujących się z kraju emigracyjnego w emigracyjno-imigracyjny (Szylko-Skoczny, Duszczyk, 2010), cały czas jednak widoczna jest w jej przypadku przewaga emigracji nad imigracją (Godlewska, 2010). Jednocześnie Polska pozostaje krajem o jednolitej strukturze narodowościowej. Według danych GUS liczba obcokrajowców mieszkająca na stałe w Polsce w 2011 r. wynosiła 55,4 tys. osób (0,1\% ogółu mieszkańców). Z kolei według danych z Urzędu do Spraw Cudzoziemców z 31 grudnia 2011 r. ważne karty pobytu w Polsce posiadało 100298 obcokrajowców. Mimo tych różnic 
dane te potwierdzają, iż w Polsce liczba obcokrajowców jest wciąż niewielka w stosunku do ogółu mieszkańców kraju. Dodatkowo nasz kraj jako jeden z najbiedniejszych w Unii Europejskiej nie jest atrakcyjny dla imigrantów zagranicznych (Iglicka, 2008), zwłaszcza z krajów lepiej rozwiniętych gospodarczo. Równocześnie wzrasta liczba obcokrajowców posiadających ważne karty pobytu w Polsce (Szylko-Skoczny, Duszczyk 2010). Są to głównie obywatele państw Europy Wschodniej (Rosja, Ukraina, Białoruś) oraz Azji (m.in. Wietnam, Irak, Armenia).

Celem artykułu jest ukazanie zróżnicowania przestrzennego imigracji na stałe do Polski zarówno ze względu na kraj poprzedniego miejsca zamieszkania, jak i obszary napływowe w Polsce. W artykule przedstawiono również charakterystykę imigrantów na stałe do Polski wedle wybranych cech oraz podjęto próbę wyjaśnienia przyczyn zmian natężenia napływu imigrantów na stałe do naszego kraju w ostatnich latach. Przy pisaniu artykułu korzystano przede wszystkim z danych Głównego Urzędu Statystycznego, Eurostatu oraz Urzędu do Spraw Cudzoziemców. Dane w artykule pozwalają przedstawić jedynie zarys ruchów imigracyjnych na stałe do Polski i wskazać panujące tendencje w zakresie jego natężenia oraz zróżnicowania przestrzennego. Należy przy tym pamiętać o zasadniczej różnicy pomiędzy migracjami na stałe a migracjami czasowymi powyżej trzech miesięcy. Migracje na stałe dotyczą osób które wywiązały się z obowiązku meldunkowego i zostały uwzględnione w oficjalnych statystykach. Mają one charakter trwały, osiedleńczy. Z kolei migracje na pobyt czasowy dotyczą stałych mieszkańców innych krajów, którzy zameldowali się na pobyt czasowy w Polsce. Zarówno liczba migrantów stałych, jak i czasowych jest zaniżona ze względu na to, że nie wszyscy migranci dokonują obowiązku zameldowania. Nie są to więc dane rzeczywiste, a jedynie dotyczące tych migrantów, którzy spełnili obowiązek prawny (GUS). Dane te pozwalają jednak zaobserwować główne kierunki migracyjne, ich zróżnicowanie przestrzenne w układach lokalnych oraz scharakteryzować migrantów według wybranych wskaźników demograficznych. Ponadto w artykule imigrację przedstawiano w rozumieniu definicji z Rocznika Demograficznego z 2012 roku jako ,przybycie do kraju osoby będącej uprzednio rezydentem innego kraju z zamiarem przebywania przez okres co najmniej 12 miesięcy" (GUS, 2012). Oznacza to, iż do imigrantów zaliczano również Polaków, którzy posiadali status rezydenta w innym kraju, a zdecydowali się na dłuższy pobyt w Polsce. W artykule zastosowano opis statystyczny oraz analizę literatury przedmiotu. Dane w artykule przedstawiono za pomocą kartogramów i kartodiagramów. Zakres czasowy artykułu obejmuje lata 1966-2011.

\section{NATĘŻENIE I KIERUNKI IMIGRACJI NA STAŁE Do PolSKI W LATACH 1966-2011}

Liczba osób przybywających na stałe do Polski od 1966 do 1983 r. znajdowała się na względnie jednakowym, niskim poziomie, nie przekraczając 2,3 tys. imigrantów na rok (najmniej w 1983 r., gdy odnotowano 0,5 tys. imigrantów). W kolejnych latach poziom natężenia imigracji na stałe do Polski systematycznie wzrastał do 17,4 tys. osób w 2009 roku. W latach 
2010 i 2011 natężenie imigracji na stałe do Polski spadło i wyniosło odpowiednio 15,2 i 15,5 tys. osób. Powyższe dane jednoznacznie wskazują na wzrost zainteresowania przyjazdami do naszego kraju przez obcokrajowców. W porównaniu z innymi państwami Unii Europejskiej napływ imigrantów do Polski jest jednak wciąż niski (Weinar, 2006). Większy napływ obcokrajowców stanowi wyzwanie dla instytucji publicznych w Polsce zajmujących się m.in. rynkiem pracy, ubezpieczeniami czy pomocą społeczną, które nie są obecnie na to odpowiednio przygotowane (Duszczyk, Góra, 2012).

Z kolei poziom emigracji na stałe z Polski charakteryzował się dużą zmiennością. W latach 1966-1990 wahał się od 9,6 tys. osób w 1975 r. do 36,4 tys. osób w 1987 r. Następnie do 2005 r. poziom natężenia emigracji na stałe z Polski względnie unormował się (od 18,1 tys. osób w 1992 r. do 27 tys. osób w 2000 r.). Nagły wzrost odpływu emigrantów na stałe z Polski nastąpił w 2006 r., kiedy w porównaniu z poprzednim rokiem wyjechało ponad dwukrotnie więcej osób - z poziomu 22,2 tys. do 46,9 tys. osób. Był to pośredni skutek wstąpienia Polski do Unii Europejskiej w 2004 r., otwierania się kolejnych unijnych rynków pracy oraz pozytywnych doświadczeń pierwszych polskich emigrantów do krajów unijnych z drugiej połowy 2004 oraz 2005 r. W kolejnych latach 2007-2010 następował spadek natężenia emigracji na stałe z Polski do 17,3 tys. osób. Przyczynami były światowy kryzys gospodarczy, który rozpoczął się w 2007 r., oraz masowe wyjazdy polskiej ludności w pierwszych latach po przystąpieniu Polski do Unii Europejskiej, kiedy wyjechali najbardziej zdeterminowani emigranci (Kaczmarczyk, 2010). W 2011 r. nastąpiło odwrócenie tej tendencji (wzrost emigrantów na stałe z Polski do poziomu 19,9 tys. osób). Było to związane z brakiem perspektyw na rodzimym rynku pracy oraz ustępującym światowym kryzysem gospodarczym.

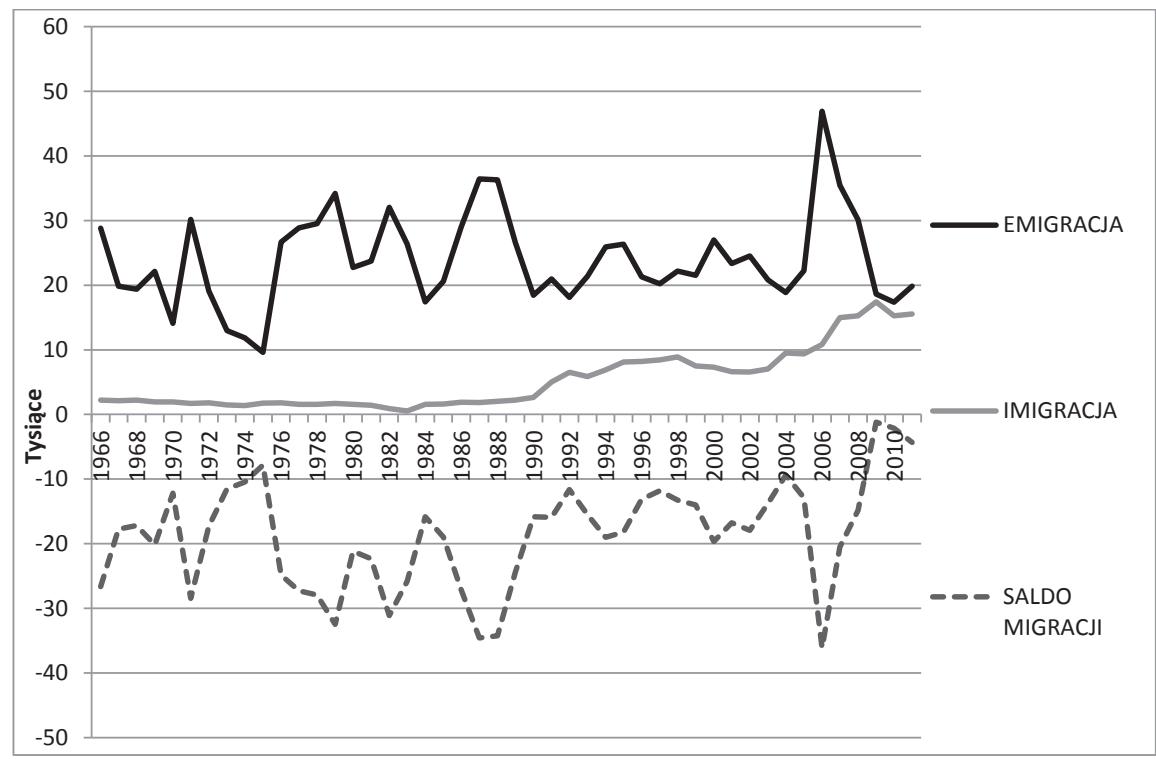

Ryc. 1. Migracje zagraniczne na pobyt stały w latach 1966-2011

Źródło: opracowanie na podstawie danych GUS opublikowanych w „Główne kierunki emigracji i imigracji w latach 1966-2008" oraz z bazy Demografia 
W związku z niskimi wartościami natężenia imigracji na stałe do Polski oraz względnie wysokimi wartościami natężenia emigracji z Polski te ostatnie miały główny wpływ na kształtowanie się salda migracji zagranicznych na stałe dla naszego kraju, charakteryzującego się dużą zmiennością natężenia oraz ujemnymi wartościami (najniższe -34,6 tys. osób w 1987 roku). Dopiero w ostatnich latach w wyniku wzrostu natężenia imigracji oraz spadku natężenia emigracji i niemal zrównania się obydwu wskaźników saldo migracji na stałe dla Polski wzrosło do poziomu -1,2 tys. osób w 2009 r. W ostatnich dwóch latach saldo imigracji na stałe do Polski spadło jednak do poziomu -4,3 tys. osób w 2011 roku.

\section{IMIGRACJE NA STAŁE A IMIGRACJE NA POBYT CZASOWY POWYŻEJ TRZECH MIESIĘCY}

Najnowsze dane dotyczące imigracji na pobyt czasowy dotyczą 2011 r. (Rocznik Demograficzny 2012). Odnotowano wówczas 15,5 tys. przyjazdów na stałe oraz 65,9 tys. przyjazdów czasowych powyżej trzech miesięcy do Polski. W związku z tym imigracje czasowe powyżej trzech miesięcy miały 4,2-krotnie większe natężenie od imigracji stałych do Polski.

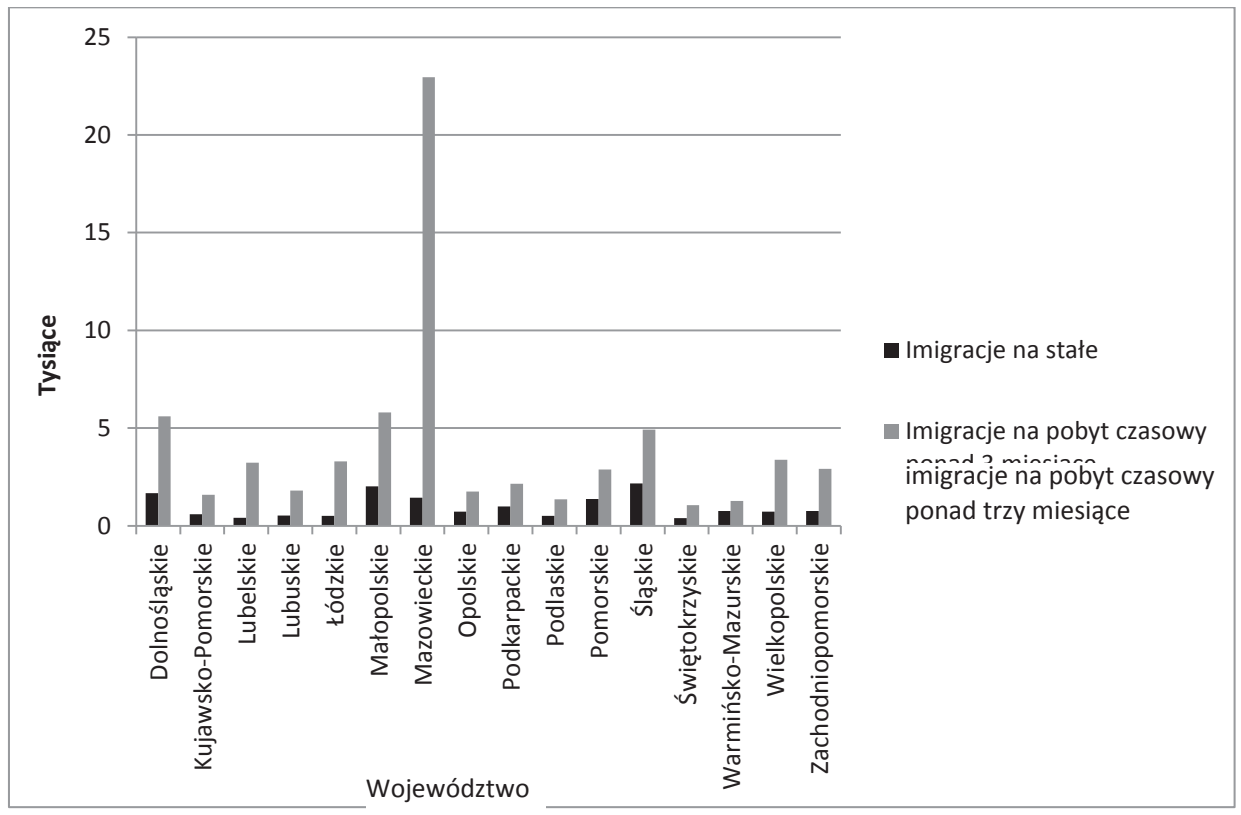

Ryc. 2. Natężenie imigracji zagranicznych stałych i czasowych powyżej trzech miesięcy do Polski w 2011 r. według województw

Źródło: opracowanie na podstawie danych z Rocznika Demograficznego 2012

We wszystkich 16 polskich województwach imigracje czasowe powyżej trzech miesięcy przewyższały swoim natężeniem imigracje na stałe. Najwięcej imigrantów na stałe osiedliło się w województwach: śląskim (2,2 tys. osób), małopolskim (2 tys. osób), dolno- 
śląskim (1,7 tys. osób) i mazowieckim (1,4 tys. osób). Imigranci czasowi osiedlali się najczęściej w tych samych województwach. Najwięcej z nich przybyło do województwa mazowieckiego (23 tys. osób), małopolskiego (5,8 tys. osób), dolnośląskiego (5,6 tys. osób) i śląskiego (4,9 tys. osób). Imigranci napływali więc głównie do województw najbardziej rozwiniętych gospodarczo w kraju z najlepszymi perspektywami zatrudnienia.

\section{RuCH WIZOWY}

Dane dotyczące imigracji do Polski z krajów objętych ruchem wizowym są zdecydowanie bliższe rzeczywistej skali napływowej. Wśród typów wiz szczególne znaczenie mają wizy repatriacyjne oraz te przyznawane uchodźcom.

\section{Repatriacje}

W latach 1997-2010 najwięcej wiz repatriacyjnych przyznano ludności polskiego pochodzenia z Kazachstanu (53,3\%), Ukrainy (24,2\%) oraz Białorusi (10,9\%). Pozostałe 11,6\% wiz repatriacyjnych przyznano ludności polskiego pochodzenia z Federacji Rosyjskiej, Uzbekistanu, Armenii, Azerbejdżanu, Gruzji, Niemiec, Litwy, Łotwy, Mołdawii i Republiki Czeskiej.

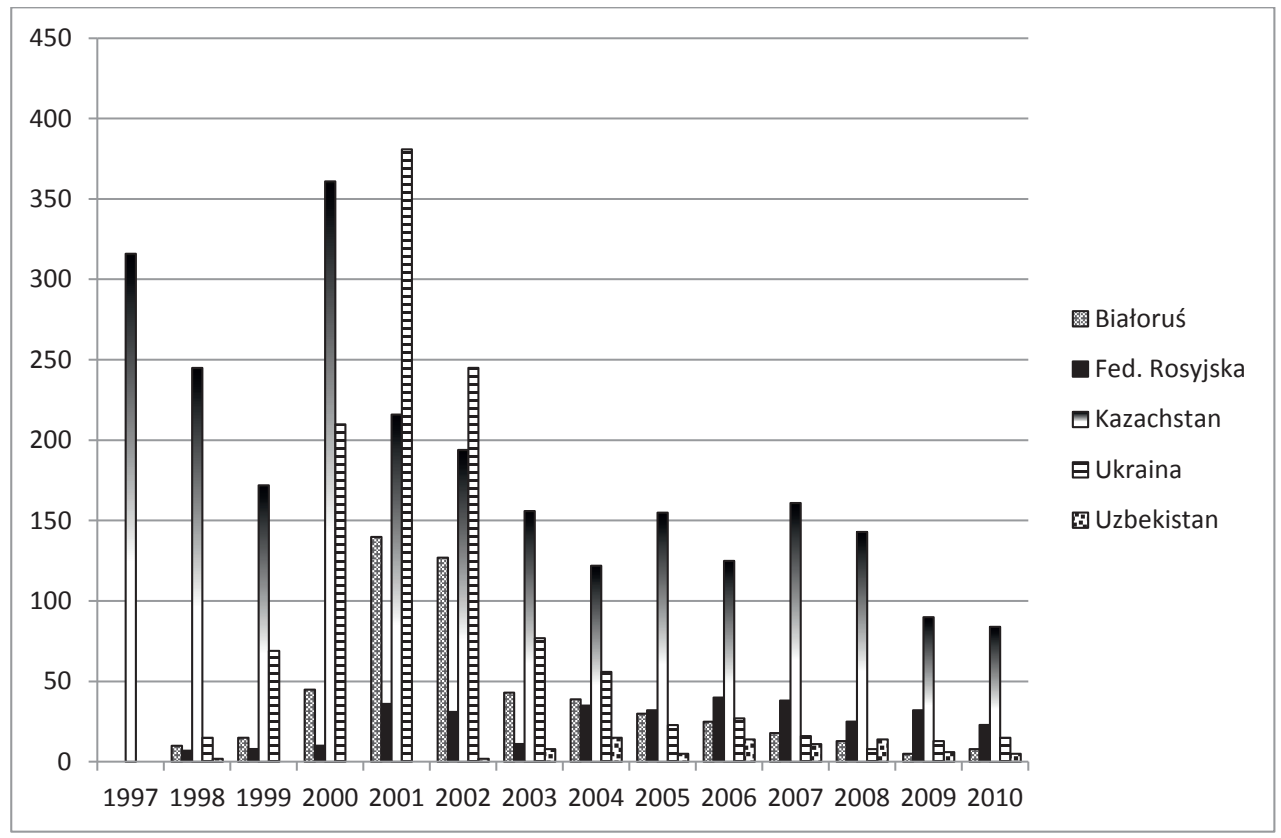

Ryc. 3. Przyznane wizy repatriacyjne do Polski według krajów w latach 1997-2010 cz. 1

Źródło: opracowanie na podstawie danych z Grzymała-Moszczyńska, Grzymała-Kazłowska, 2011 


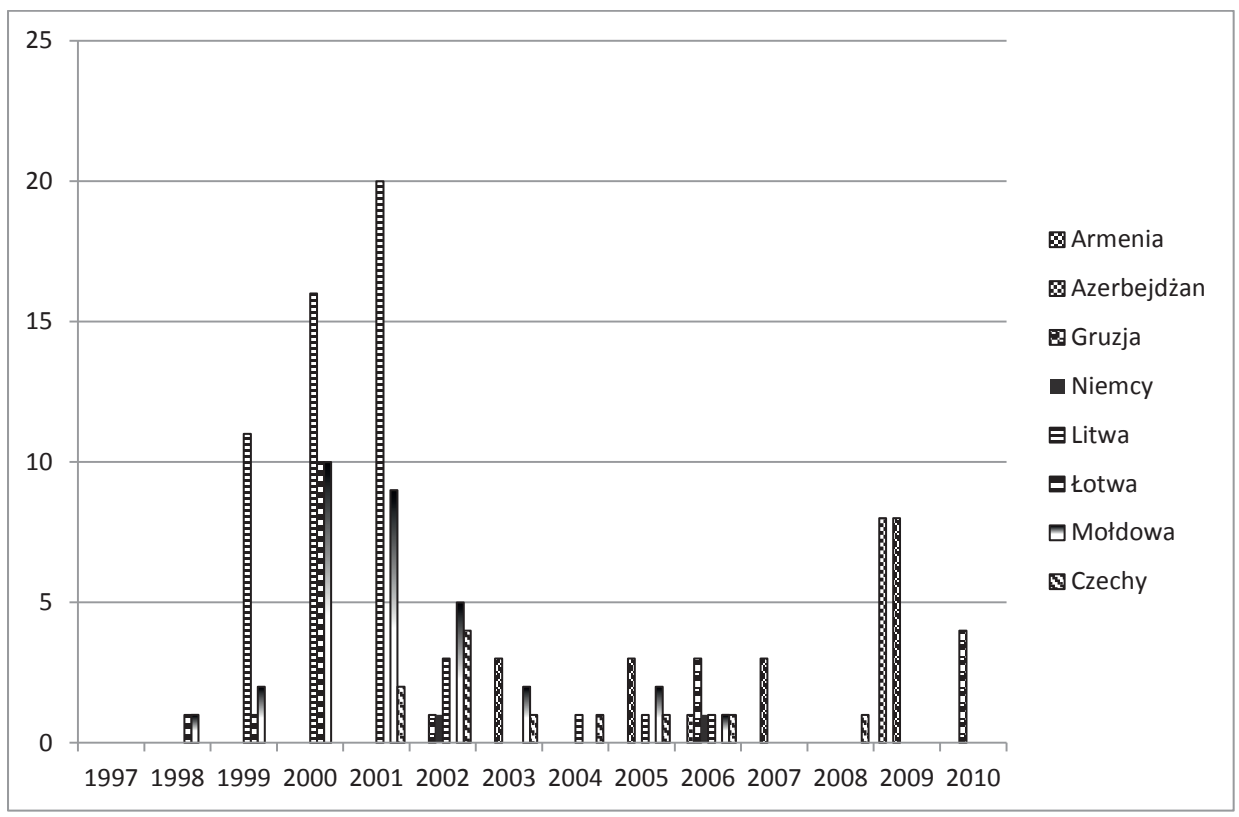

Ryc. 4. Przyznane wizy repatriacyjne do Polski według krajów w latach 1997-2010 cz. 2

Źródło: opracowanie na podstawie danych z Grzymała-Moszczyńska, Grzymała-Kazłowska, 2011

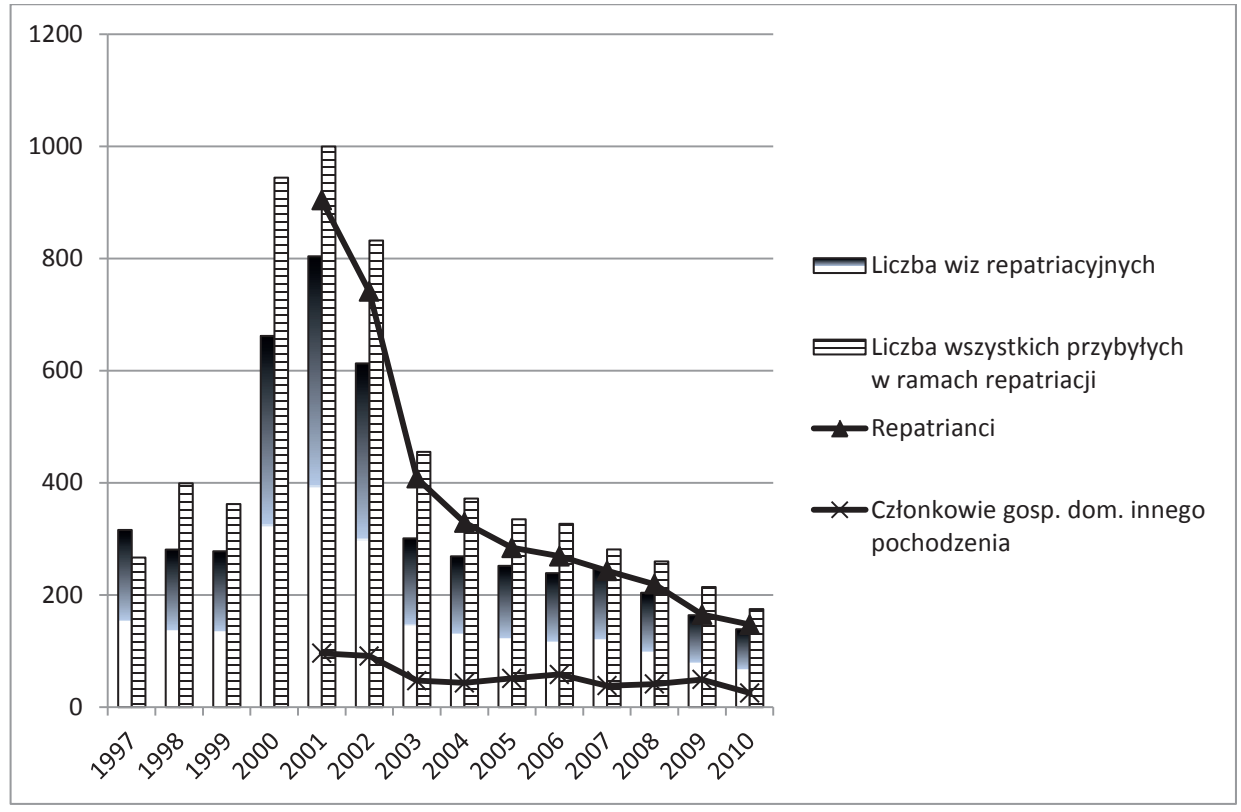

Ryc. 5. Wydane wizy repatriacyjne oraz napływ ludności objętej ustawą repatriacyjną

Źródło: opracowanie na podstawie danych z Grzymała-Moszczyńska, Grzymała-Kazłowska, 2011 
W latach 1997-2010 wydano 4770 wiz repatriacyjnych. W tym czasie do Polski przyjechały 6223 osoby objęte ustawą repatriacyjną. W latach 2001-2010 87,31\% przybyłych stanowili repatrianci, natomiast $12,69 \%$ członkowie gospodarstw domowych innego pochodzenia. Od roku 2001 spada zarówno natężenie liczby przybyłych do Polski osób w ramach repatriacji, jak i liczba wydawanych wiz repatriacyjnych.

\section{Uchodźcy i pozostali imigranci objęci ruchem wizowym}

Należy pamiętać również o uchodźcach, którzy zostali przyjęci przez nasz kraj. Od podpisania Konwencji genewskiej w 1991 r. Polska przyjęła duże grupy uchodźców m.in. z: Armenii, Czeczenii, Bośni, Kosowa, Afganistanu, Iraku, Sri Lanki, Somalii i Sudanu (Halik, Kosowicz, Marek, 2009).

Według danych zawartych w sprawozdaniu rocznym do Spraw Cudzoziemców (2012 r.) w 2011 r. statut uchodźcy nadano 157 osobom (w tym 153 osobom status uchodźcy nadał Szef Urzędu do Spraw Cudzoziemców, a pozostałym 4 Rada do Spraw Uchodźców), ochronę uzupełniającą 207 osobom (w tym 155 osobom przez Szefa Urzędu do Spraw Cudzoziemców oraz 52 przez Radę do Spraw Uchodźców), zgodę na pobyt tolerowany 241 osobom (w tym 173 osobom przez Szefa Urzędu do Spraw Cudzoziemców - w sprawach o nadanie statusu uchodźcy 170 , w sprawach o udzielenie zgody na pobyt tolerowany 3; 41 przez Radę do Spraw Uchodźców oraz 27 przez wojewodów).

W 2011 r. wydano również zgody na osiedlenie się 3733 osobom, zgody na zamieszkanie na czas oznaczony 29653 osobom, zgody na pobyt rezydenta długoterminowego Wspólnoty Europejskiej 765 osobom.

Wśród obcokrajowców, którzy uzyskali statut uchodźcy, dominowali Rosjanie 52,2\%, w tym Czeczeńcy (49,0\%) i Rosjanie (3,2\%), Białorusini (14,0\%) i Irakijczycy (10,2\%), w przypadku ochrony uzupełniającej: Rosjanie (87\%), Irakijczycy $(3,9 \%)$, Uzbecy $(1,9 \%)$ i Libijczycy (1,9\%), w przypadku zgody na pobyt tolerowany: Rosjanie 47,7\%, Ormianie 19,5\% oraz Mongołowie 6,2\%, w przypadku osób, które uzyskały zgodę na osiedlenie się: Ukraińcy (45,3\%), Białorusini (16,8\%) i Rosjanie (6,3\%), w przypadku osób, które uzyskały zgodę na zamieszkanie na czas oznaczony: Ukraińcy (27,5\%), Chińczycy (9,2\%), Wietnamczycy (6,5\%), w przypadku osób, które uzyskały zgodę na pobyt rezydenta długoterminowego Wspólnoty Europejskiej Ukraińcy (33,9\%), Wietnamczycy (15,2\%) i Ormianie $(7,1 \%)$.

\section{Ważne karty pobytu w Polsce według stanu na koniec 2011 r.}

Według stanu na 31 grudnia 2011 r. obecnie ważne karty pobytu w Polsce wedle poszczególnych ich rodzajów posiada 100298 osób, w tym 3012 dotyczy ochrony uzupełniającej, 47999 osiedlenia się, 5732 pobytu rezydenta długoterminowego Wspólnoty Europejskiej, 738 pobytu tolerowanego, 1170 statusu uchodźcy, 41647 zamieszkania na 
czas oznaczony. O karty pobytu w Polsce ubiegali się głównie obywatele państw azjatyckich. Wśród osób posiadających karty pobytu ze względu na ochronę uzupełniającą dominują obywatele: Rosji (2788 osób, 92,6\% wszystkich kart), Iraku (37 osób, 1,2\%), Afganistanu (30 osób, 1\%) i Sri Lanki (30 osób, 1\%). W przypadku kart pobytu ze względu na osiedlenie się przewodzą obywatele: Ukrainy (15 919 osób, 33,2\%), Białorusi (6043 osób, 12,6\%), Rosji (4867 osób, 10,1\%) i Wietnamu (4437 osób, 9,2\%). Większość kart pobytu ze względu na pobyt rezydenta długoterminowego Wspólnoty Europejskiej należy do obywateli: Ukrainy (2002 osoby, 34,9\%), Wietnamu (1032 osoby, 18\%), Armenii (495 osób, 8,6\%) i Rosji (429 osób, 7,5\%). W zakresie kart pobytu na pobyt tolerowany dominowali obywatele: Wietnamu (252 osoby, 34,1\%), Armenii (107 osób, 14,5\%), Rosji (105 osób, 14,2\%) i Ukrainy (67 osób, 9,1\%). Status uchodźcy posiadają głównie obywatele: Rosji (828 osób, 70,8\%), Białorusi (119 osób, 10,2\%) i Iraku (45 osób, 3,8\%), natomiast karty pobytu ze względu na zamieszkanie na czas oznaczony obywatele: Ukrainy (11 750 osób, 28,2\%), Wietnamu (3532 osób, 8,5\%) i Chin (3145 osób, 7,6\%).

Powyższe dane dotyczące posiadanych obecnie kart pobytu oraz osób, które uzyskały wizy w 2011 r., wskazują, iż ubiegali się o nie głównie obcokrajowcy z państw sąsiednich, nienależących do Unii Europejskiej (Rosja, Ukraina, Białoruś), oraz państw, w których trwają bądź przebiegały różnego typu konflikty (m.in. Wietnam, Armenia, Irak).

\section{Charakterystyka IMigRantów Zagranicznych na POByt STAŁy do POLSKI}

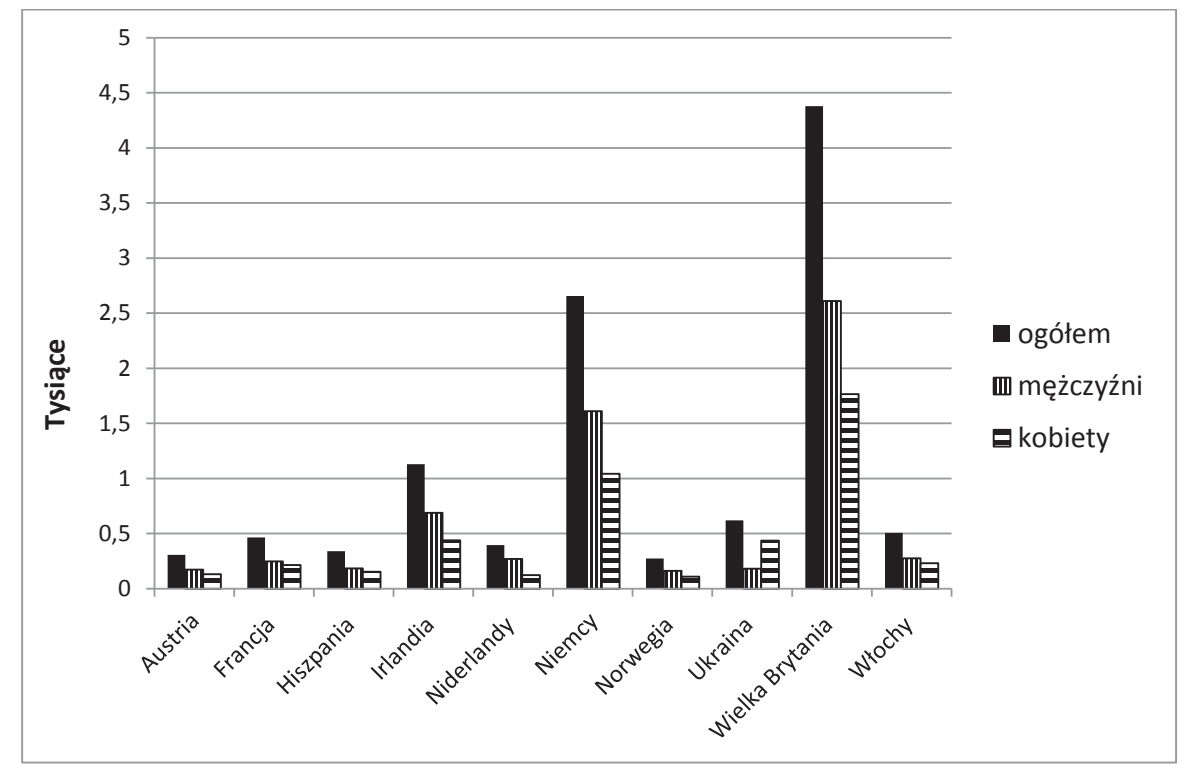

Ryc. 6. Imigranci na stałe do Polski w 2011 r. według kraju poprzedniego miejsca zamieszkania (z krajów europejskich)

Źródło: opracowanie na podstawie danych z Rocznika Demograficznego 2011 
Imigranci na stałe do Polski w 2011 r. pochodzili głównie z: Wielkiej Brytanii (4,4 tys. osób - 28,2\% ogółu imigrantów na stałe do Polski), Niemiec (2,7 tys. osób - 17,1\%) i Irlandii (1,1 tys. osób - 7,3\%). W przypadku krajów pozaeuropejskich największy udział imigrantów na stałe do Polski był ze: Stanów Zjednoczonych (1,6 tys. osób - 10,1\%), Kanady (0,4 tys. osób - 2,4\%) i Australii (0,1 tys. osób - 0,9\%). W przeciągu kilkunastu lat nastąpiła zmiana w zakresie pochodzenia imigrantów do Polski w związku z nową sytuacją polityczną naszego kraju. W latach 1996-2004, gdy Polska nie była jeszcze członkiem Unii Europejskiej, imigranci przybywali głównie z Niemiec (30\%), Stanów Zjednoczonych (16\%) i Ukrainy (7\%) (Długosz, 2007), natomiast obecnie zwiększyło się natężenie imigracji z krajów Europy Zachodniej.

Większość imigrantów na stałe do Polski w 2011 r. stanowili mężczyźni - 8,9 tys. (57,1\%) w stosunku do 6,7 tys. kobiet (42,9\%). Spośród wybranych krajów o największym natężeniu przypływu imigrantów na stałe do Polski w 2011 r. (za wyjątkiem dwóch państw) przeważała ludność płci męskiej. Największy udział mężczyzn wystąpił w przypadku imigracji z: Turcji (83\%), Niderlandów (69\%), Wietnamu (64\%) i Armenii (62\%), natomiast kobiet z Ukrainy (71\%) i Kazachstanu (62\%).

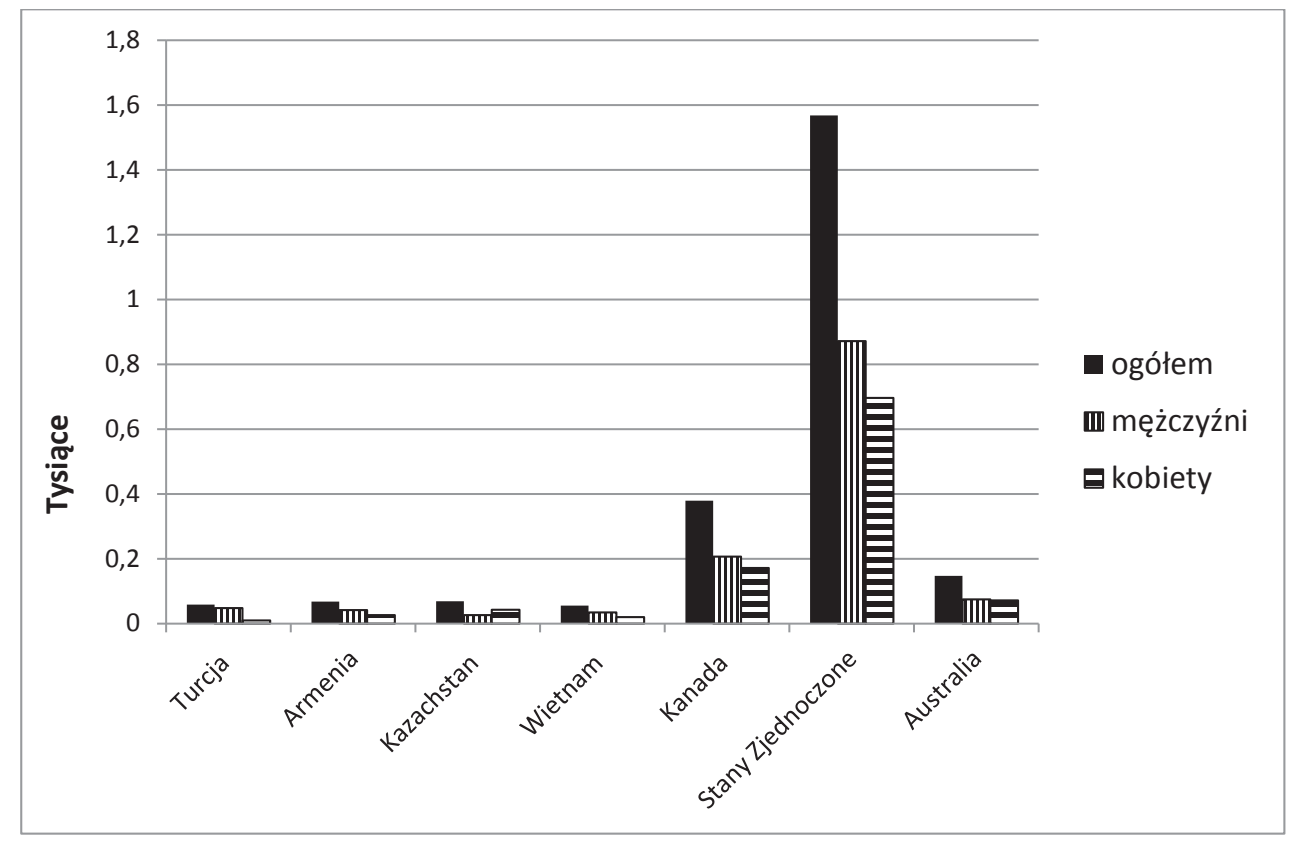

Ryc. 7. Imigranci na stałe do Polski w 2011 r. według kraju poprzedniego miejsca zamieszkania (z krajów pozaeuropejskich)

Źródło: opracowanie na podstawie danych z Rocznika Demograficznego 2011 


\section{Imigranci według obywatelstwa}

Według danych Głównego Urzędu Statystycznego przeważającą część imigrantów na stałe do Polski w 2011 r. stanowili obywatele polscy (13 843 osoby, 89,2\% ogółu imigrantów), a następnie obywatele: Ukrainy (508 osób, 3,3\%), Białorusi (166 osób, 1,1\%), Rosji (103 osoby, 0,7\%) i Niemiec (78 osób, 0,5\%). Imigranci na stałe pozostałych narodowości stanowili łącznie 5,3\% (826 osób) ogółu przyjeżdżających na stałe do Polski w 2011 r.

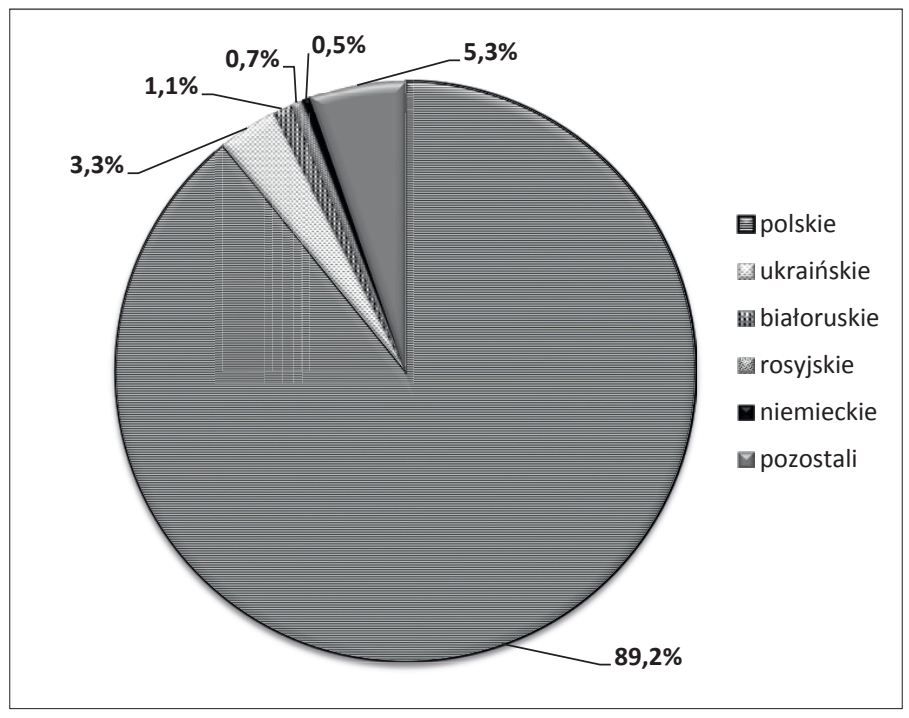

Ryc. 8. Imigranci na stałe do Polski według obywatelstwa w $2011 \mathrm{r}$.

Źródło: opracowanie na podstawie danych GUS z bazy Demografia

Podsumowując imigrację zagraniczną na stałe według obywatelstwa oraz kraju poprzedniego miejsca zamieszkania, w przypadku 10 kierunków europejskich o największym natężeniu przyjazdów do Polski przeważały przyjazdy obywateli polskich nad obywatelami innych krajów. Największy udział Polaków wystąpił w przypadku napływu migrantów z Irlandii (99,7\%), Wielkiej Brytanii (99\%) i Norwegii (98,2\%). Jedyny wyjątek stanowił napływ imigrantów z Ukrainy, wśród których zaledwie 18,3\% stanowili obywatele polscy.

W przypadku 7 kierunków pozaeuropejskich o największym natężeniu imigracji zagranicznych na stałe do Polski imigranci z polskim obywatelstwem przeważali nad imigrantami z obywatelstwem innych krajów w przypadku przyjazdów z Kanady (97,4\%), Stanów Zjednoczonych (97,3\%), Australii (96,6\%) i Kazachstanu (72,5\%). Polacy natomiast stanowili mniejszość wśród imigrantów z Turcji (31\%), Armenii (14,7\%) i Wietnamu (1,8\%).

Powyższe dane wskazują, iż Polacy dominowali wśród imigrantów w przypadku przyjazdów z krajów Europy Północnej i Zachodniej oraz państw, z którymi mamy bogatą historię migracyjną, natomiast obcokrajowcy dominowali w przypadku przyjazdów z krajów słabiej rozwiniętych gospodarczo. 


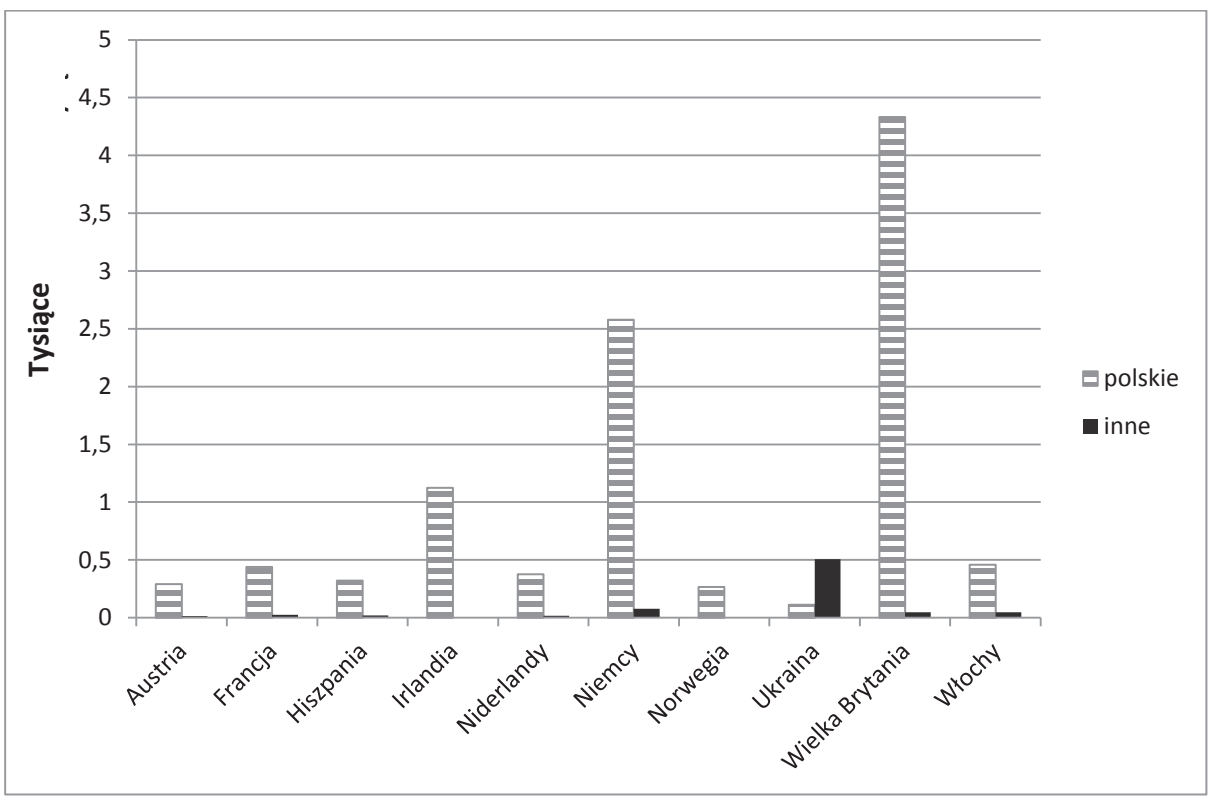

Ryc. 9. Imigranci na stałe do Polski według obywatelstwa

oraz krajów poprzedniego miejsca zamieszkania w 2011 r. (z krajów europejskich)

Źródło: opracowanie na podstawie danych GUS z bazy Demografia

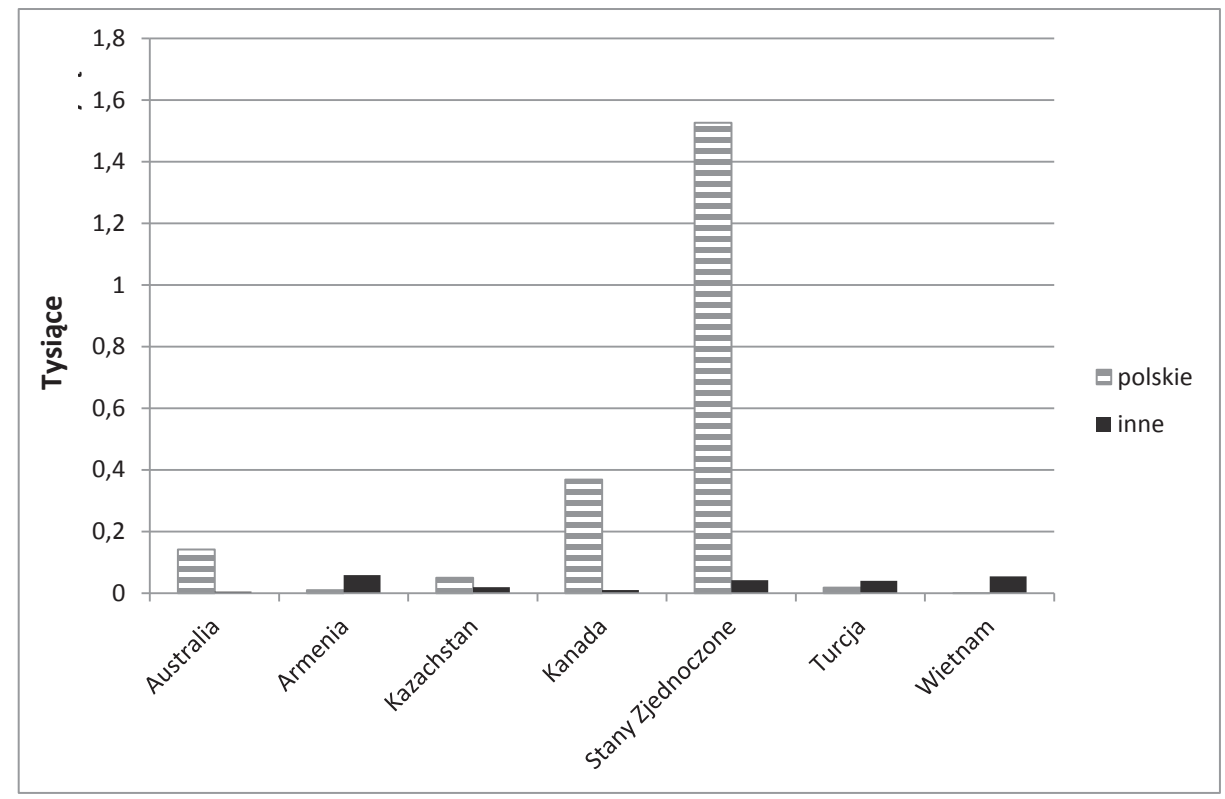

Ryc. 10. Imigranci na stałe do Polski według obywatelstwa oraz krajów poprzedniego miejsca zamieszkania w 2011 r. (z krajów pozaeuropejskich)

Źródło: opracowanie na podstawie danych GUS z bazy Demografia 


\section{Struktura wieku imigrantów}

W strukturze wieku imigrantów na stałe do Polski w 2011 r. zauważalny był wysoki udział dzieci od urodzenia do lat pięciu (36\% dziewczynek spośród ogółu imigrantów płci żeńskiej oraz $28 \%$ chłopców spośród ogółu imigrantów płci męskiej). Na tak wysoki udział dzieci w strukturze imigrantów pewien wpływ ma wysoki przyrost naturalny wśród polskich emigrantów, którzy w celu wyrobienia dowodu tożsamości dla swoich dzieci, a wcześniej uzyskania numeru PESEL, meldują je w Polsce. W rezultacie dzieci te zaliczane są do imigrantów na stałe do Polski. Dodatkowo znaczna część dorosłych imigrantów, którzy przyjeżdżają do Polski, nie wypełnia obowiązku meldunkowego, dlatego struktura wieku wśród starszych imigrantów jest zaniżona.

Wśród pozostałych imigrantów dominowali ludzie młodzi. W większości były to prawdopodobnie osoby, które zdecydowały się na powrót na stałe do Polski w wyniku niepowodzenia na zagranicznych rynkach pracy.

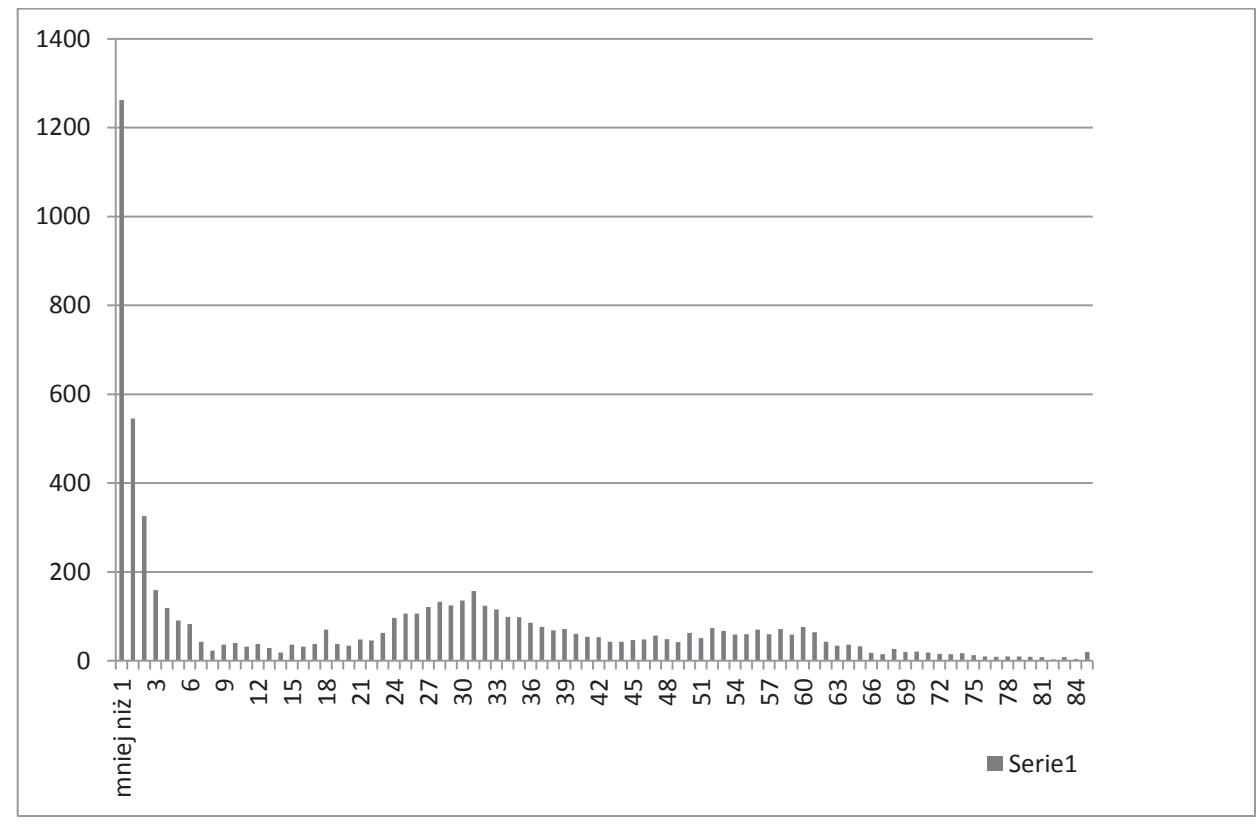

Ryc. 11. Struktura wieku imigrantów na stałe do Polski w 2011 r.

Źródło: opracowanie na podstawie danych z Banku Danych Lokalnych

\section{Imigranci według stanu cywilnego}

W 2011 r. wśród imigrantów na stałe do Polski było 48\% osób stanu wolnego, 30\% stanowili małżonkowie, $17 \%$ osób o nieustalonym stanie cywilnym, $4 \%$ osoby rozwiedzione, a $1 \%$ stanowili wdowcy i wdowy. 


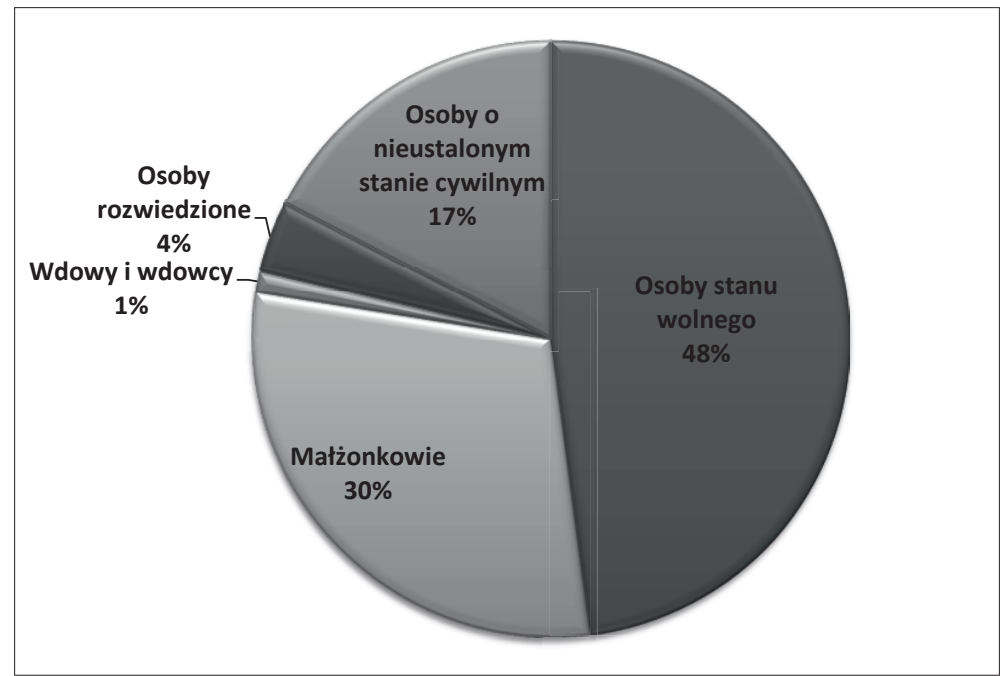

Ryc. 12. Imigranci na stałe do Polski według stanu cywilnego w $2011 \mathrm{r}$.

Źródło: opracowanie na podstawie danych GUS z bazy Demografia

\section{IMIGRACJE ZAGRANICZNE NA POBYT STAŁY DO POLSKICH MIAST I WSI}

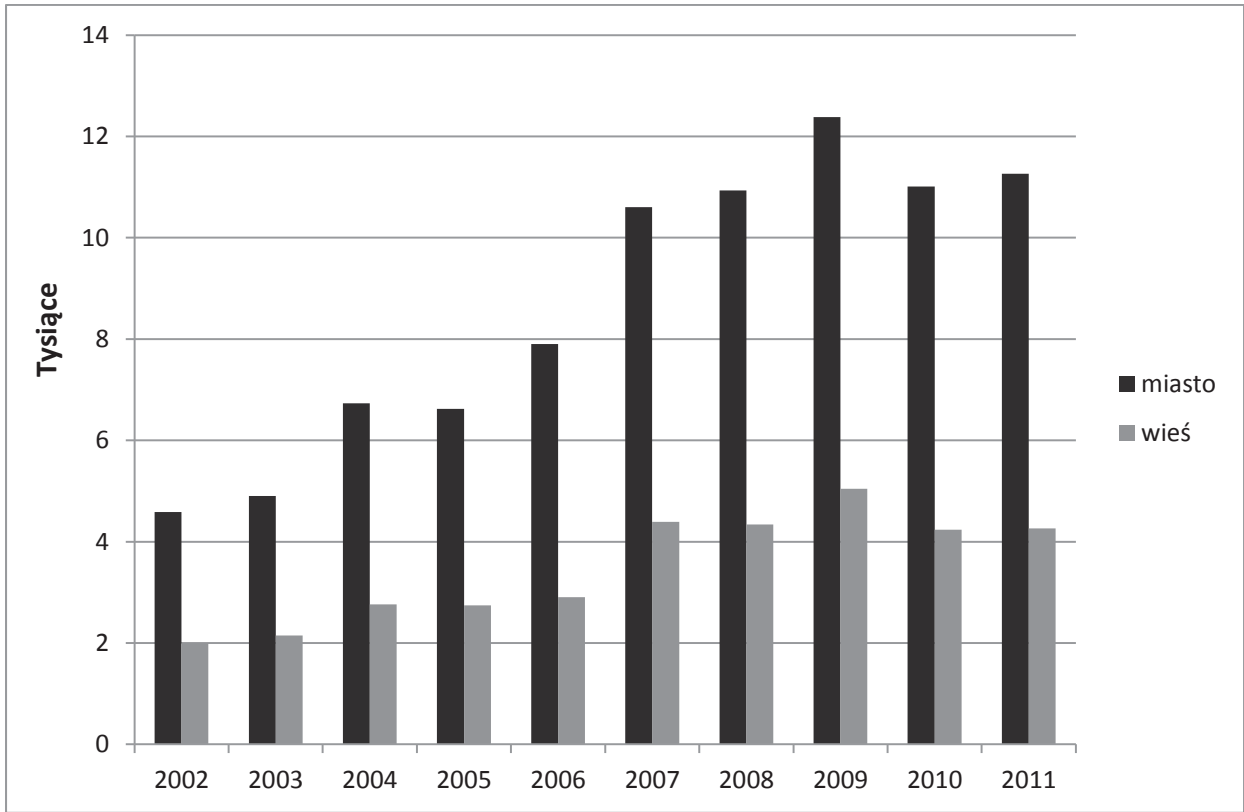

Ryc. 13. Imigracje zagraniczne na stałe do Polski w latach 2002-2011 według kierunku miasto-wieś Źródło: opracowanie na podstawie danych GUS z bazy Demografia 
Większość imigracji zagranicznych na stałe do Polski w latach 2002-2011 była skierowana do polskich miast $(71,4 \%)$ w stosunku do imigracji na wieś $(28,6 \%)$, co jest tendencją odwrotną niż obserwowane procesy suburbanizacji w migracjach wewnętrznych, cechujące się przenoszeniem się z miast na wieś (Raźniak, Winiarczyk-Raźniak, 2013; Zborowski, Raźniak, 2013). Taka centralizacja ruchu imigracyjnego do ośrodków miejskich związana jest m.in. z bardziej chłonnymi rynkami pracy (Warych-Juras, Gałka, 2009), a także z miejskim pochodzeniem większości imigrantów do Polski. Ponadto miasta zapewniają wyższy poziom bezpieczeństwa społecznego (Raźniak, 2012). Z kolei większość imigrantów powrotnych do Polski osiedla się zazwyczaj w czterech województwach: mazowieckim, małopolskim, śląskim i dolnośląskim, w tym przede wszystkim w miastach, m.in.: Warszawie, Krakowie, Wrocławiu oraz rzadziej Trójmieście i Poznaniu (Fihel, Tyrowicz, Kaczmarczyk, 2008). Największy napływ imigracji zagranicznej do polskich miast wystąpił w 2006 roku (73,13\%), natomiast najmniejszy w 2003 r. $(69,57 \%)$.

\section{ZRÓŻNICOWANIE PRZESTRZENNE IMIGRACJI NA STAŁE DO POLSKI}

W UKŁADZIE GMINNYM

Imigracje na stałe do Polski w latach 1995-1997 nie były zbytnio zróżnicowane pod względem kierunków docelowych napływu ludności według gmin w Polsce. Największe natężenie imigracji wystąpiło w gminach województwa opolskiego (głównie od 2,5 do 4,9 oraz od 5 do 7,4, a także od 7,5 do 9,9 imigrantów na stałe na 10 tys. mieszkańców), okolicach Szczecina (od 5 do 7,4 imigrantów na stałe na 10 tys. mieszkańców), Trójmiasta (od 7,5 do 9,9 imigrantów na stałe na 10 tys. mieszkańców, jednak w nielicznych gminach), Zakopanego (w kilku gminach od 7,5 do 9,9 oraz 10-40,1 imigrantów na stałe na 10 tys. mieszkańców) i Sandomierza (zazwyczaj od 2,5 do 4,9 imigrantów na stałe na 10 tys. mieszkańców). W gminach z okolic Olsztyna, Białegostoku, Warszawy i Tarnowa natężenie imigracji na stałe utrzymywało się zazwyczaj na poziomie od 2,5 do 4,9 osób na 10 tysięcy mieszkańców. W całym kraju natężenie imigracji na stałe miało stosunkowo niskie wartości. W pozostałych częściach kraju odnotowano śladowe natężenie imigracji na stałe do Polski na poziomie od 0 do 2,4 przybyłych na stałe osób z zagranicy na 10 tys. mieszkańców.

W latach 2002-2004 natężenie imigracji na stałe do Polski wzrosło, co uwidoczniło się zwłaszcza w gminach województwa opolskiego - w znacznej ich części natężenie imigracji zagranicznych na stałe wynosiło od 10 do 34,5 przybyłych osób na 10 tys. mieszkańców. Wysokie natężenie imigracji na stale do Polski utrzymało się w okolicach Zakopanego (zazwyczaj od 7,7 do 9,9 osób na 10 tys. mieszkańców). W gminach z okolic Szczecina, Trójmiasta i Sandomierza, które w latach 1995-1997 wyróżniały się wysokim natężeniem imigracji zagranicznych na stałe, zanotowano jego spadek (często od 2,5 do 4,9 osób na 10 tys. mieszkańców). Poza wymienionymi obszarami zanotowano bardzo niskie natężenie imigracji na stałe do Polski w układzie gminnym (od 0 do 2,4 osób na 10 tys. mieszkańców). 


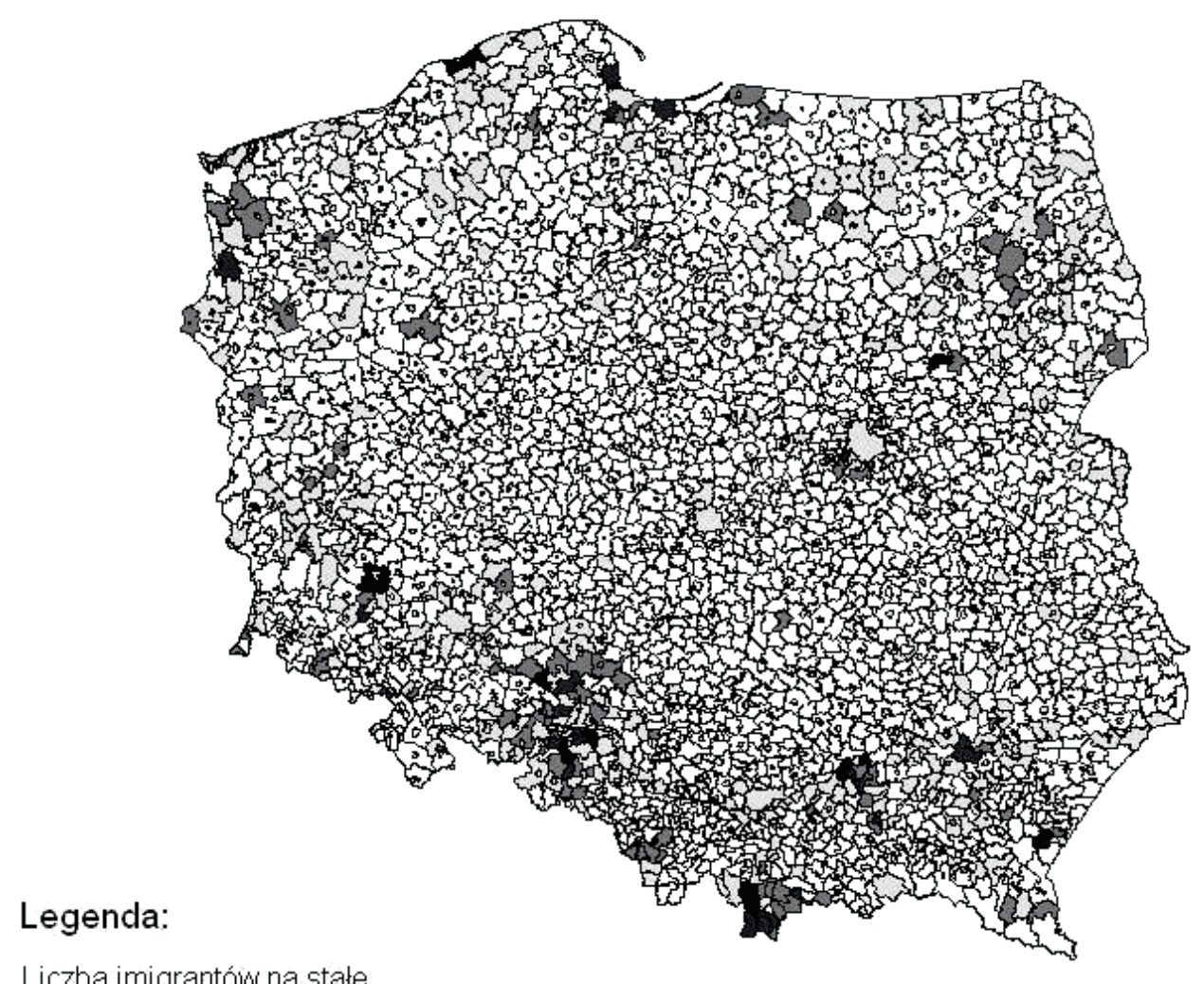

Liczba imigrantów na stałe

na 10 tys. mieszkanców

\section{$\begin{array}{lllll}2.5 & 5.0 & 7.5 & 10.0 & 40.1\end{array}$}

Ryc. 14. Średnia wielkość natężenia imigracji na stałe do Polski w układzie gminnym w latach 1995-1997 na 10 tys. mieszkańców Źródło: opracowanie na podstawie danych z Banku Danych Lokalnych 


\section{Legenda:}

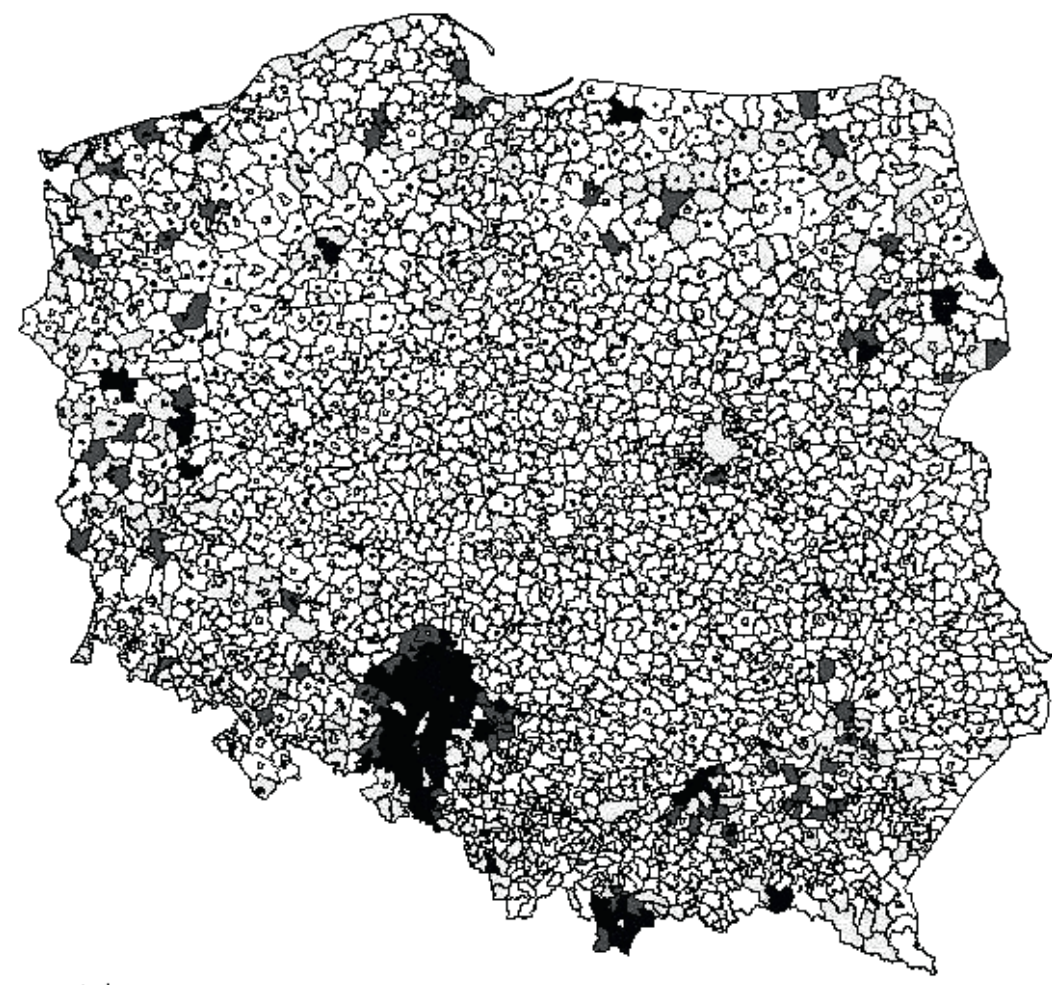

Liczba imigrantów na stałe

na 10 tys. mieszkańców

\section{$2.5 \quad 5.0 \quad 7.5 \quad 10.0 \quad 34.5$}

Ryc. 15. Średnia wielkość natężenia imigracji na stałe do Polski w układzie gminnym w latach 2002-2004 na 10 tys. mieszkańców 
W latach 2008-2010 nastąpił znaczny wzrost natężenia imigracji na stałe do Polski. W skali całego kraju widoczne było znaczne zróżnicowanie przestrzenne napływu osób, które postanowiły osiedlić się w Polsce na okres co najmniej 12 miesięcy. Najwyższe natężenie odnotowano w gminach koło Zakopanego, województwa opolskiego oraz Tarnowa (od 10 do 39,6 osób na 10 tys. mieszkańców). Wysokie natężenie imigracji odnotowano też w niektórych gminach z okolic Gorzowa Wielkopolskiego oraz z województwa pomorskiego i warmińsko-mazurskiego (od 7,5 do 9,9 oraz od 10 do 39,6 osób na 10 tys. mieszkańców). Najniższe natężenie imigracji na stałe do Polski odnotowano w gminach centralnej i wschodniej Polski (od 0 do 2,4 osób na 10 tys. mieszkańców).

Legenda:

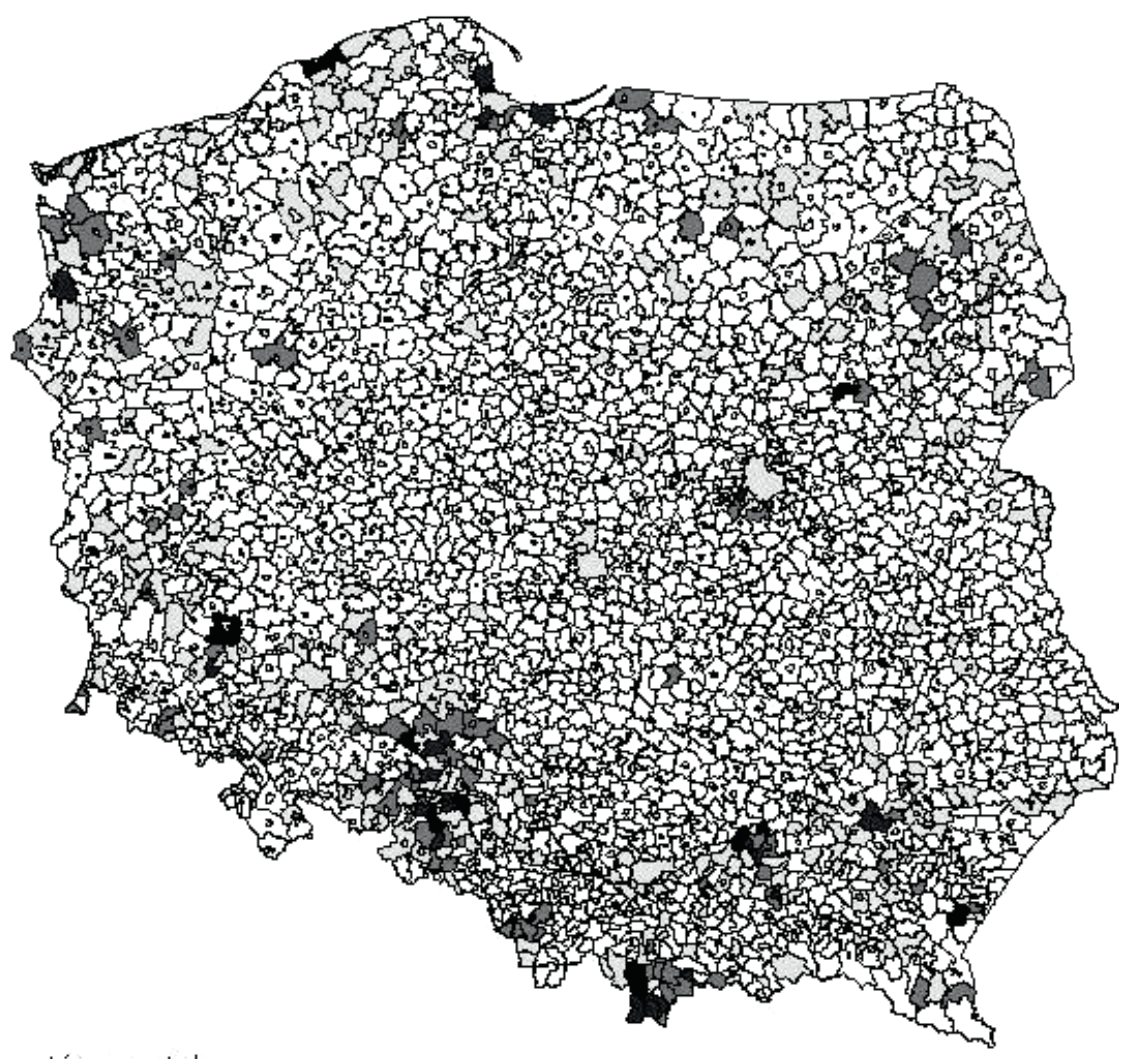

Liczba imigrantów na stałe

na 10 tys. mieszkańców

Ryc. 16. Średnia wielkość natężenia imigracji na stałe do Polski w układzie gminnym w latach 2008-2010 na 10 tys. mieszkańców

Źródło: opracowanie na podstawie danych z Banku Danych Lokalnych 


\section{Podsumowanie}

W ostatnich latach w Polsce odnotowano wzrost liczby imigrantów zagranicznych na stałe, wśród których znaczny udział miały osoby z obywatelstwem polskim. Było to związane z coraz większą liczbą emigrantów polskich głównie w krajach Unii Europejskiej, których część postanowiła wrócić do ojczyzny przede wszystkim z powodu utraty bądź trudności ze znalezieniem pracy bądź z powodów rodzinnych. Wśród obcokrajowców posiadających ważne karty pobytu w Polsce dominowali obywatele: Ukrainy, Rosji i Białorusi oraz państw azjatyckich, m.in.: Wietnamu, Iraku i Armenii. Na uwagę zasługuje również znaczny udział dzieci w ogólnej strukturze wieku imigrantów na stałe do Polski. Wiązało się to m.in. z koniecznością meldowania dzieci polskich emigrantów w Polsce w celu wyrobienia im numeru PESEL i uzyskania polskiego paszportu, a także z niewywiązywaniem się z obowiązku meldunkowego przez imigrantów przyjeżdżających do Polski. Większość imigracji na stałe do Polski w latach 2002-2011 była skierowana do polskich miast $(71,4 \%) \mathrm{w}$ stosunku do imigracji na stałe na wieś $(28,6 \%) \mathrm{w}$ związku z lepszymi możliwościami znalezienia zatrudnienia, a także przypuszczalnie miejskim pochodzeniem większości imigrantów do Polski. Największy udział imigrantów na stałe do Polski lokalnej w społeczności zaobserwowano w gminach w województwie opolskim oraz na Podhalu.

\section{Literatura}

Długosz, Z. (2007). Selected Aspects of Foreign Immigration to Poland at the Turn of the $20^{\text {th }} / 21^{\text {st }}$ Century. Bulletin of Geography, 7, 55-72.

Duszczyk, M., Góra, M. (2012). Active Inclusion of Immigrants in Poland. IZA Discussion Paper, 6427.

Fihel, A., Tyrowicz, J. Kaczmarczyk, P. (2008). Migracje powrotne Polaków. Biuletyn, 5.

Godlewska J. (2010). Migracje i imigranci w Polsce - skala, podstawy prawne, polityka. Ekspertyza przygotowana w ramach projektu EAPN Polska - razem na rzecz Europy Socjalnej. Warszawa.

Grabowska-Lusińska, I. (2010). Poakcesyjne powroty Polaków. CMR Working Papers, 43/101.

Grzymała-Moszczyńska, H., Grzymała-Kazłowska, A. (2011). Repatrianci z Kazachstanu - charakterystyka i główne problemy adaptacyjne. Opracowanie przygotowane na zlecenie Komitetu Badań nad Migracjami Polskiej Akademii Nauk. Warszawa.

Halik, T., Kosowicz, A., Marek, A. (2009). Imigranci $w$ polskim spoleczeństwie. Warszawa: Stowarzyszenie Vox Humana.

Iglicka, K. (2009). Powroty Polaków w okresie kryzysu gospodarczego. W pętli pułapki migracyjnej. Raport z badań. Raporty i Analizy, 1.

Kaczmarczyk, P. (2010). Kryzys a decyzje migracyjne Polaków. Biuletyn, 3.

Raźniak, P. (2012). Wpływ poziomu bezpieczeństwa społecznego na migracje ludności w Polsce. Bezpieczeństwo. Teoria i Praktyka, 6(4), 41-52.

Raźniak, P., Winiarczyk-Raźniak, A. (2013). Spatial Distribution and Differences in Migration Patterns and Revenues of Gminas in the Kraków Metropolitan Area. Bulletin of Geography. Socioeconomic Series, 19, 73-86.

Szylko-Skoczny, M., Duszczyk, M. (2010). Polityka imigracyjna Polski - szanse i wyzwania dla rynku pracy. Broszura podsumowująca usługę badawczą. Warszawa: Centrum Rozwoju Zasobów Ludzkich. 
Warych-Juras, A., Gałka, J. (2009). Ocena rozmiaru i kierunku napływu obcokrajowców (imigrantów) do polskich miast, w tym ich cech społeczno-demograficznych. W: A. Zborowski, (red.), Demograficzne i spoleczne uwarunkowania rewitalizacji miast w Polsce. Kraków: IRM, 61-92.

Weinar, A. (2006). Polityka wobec cudzoziemców w świetle debat parlamentarnych w Polsce, 1990 2003. Warszawa: Scholar.

Zborowski, A., Raźniak, P. (2013). Suburbanizacja rezydencjonalna w Polsce - ujęcia badawcze i ocena procesu. Studia Miejskie, 9, 37-50.

\section{Źródla danych}

„Główne kierunki emigracji i imigracji w latach 1966-2008”. GUS

Informacja Szefa Urzędu do Spraw Cudzoziemców o stosowaniu w roku 2011 ustawy z dnia 13 czerwca 2003 r. o udzielaniu cudzoziemcom ochrony na terytorium Rzeczypospolitej Polskiej (Dz.U. z 2003 r. nr 128, poz. 1176 z późn. zm.) w zakresie realizacji zobowiązań Rzeczypospolitej Polskiej wynikających z Konwencji genewskiej dotyczącej statusu uchodźców oraz Protokołu nowojorskiego dotyczącego statusu uchodźcy, Warszawa marzec 2012.

Konwencja dotycząca statusu uchodźcy sporządzona w Genewie dnia 28 lipca 1951 r. http://isip.sejm. gov.p1/DetailsServlet?id=WDU19911190515.

Główny Urząd Statystyczny (2010). Rocznik Demograficzny 2010, Warszawa.

Główny Urząd Statystyczny (2011). Rocznik Demograficzny 2011, Warszawa.

Główny Urząd Statystyczny (2012). Rocznik Demograficzny 2012, Warszawa.

\section{Inne źródła danych}

\section{Eurostat}

http://epp.eurostat.ec.europa.eu/portal/page/portal/eurostat/home/

Główny Urząd Statystyczny:

- Demografia

http://demografia.stat.gov.pl/bazademografia/

- Bank Danych Lokalnych

http://www.stat.gov.pl/bdl/app/strona.html?p_name=indeks

Iglicka K. (2013, 2 marca), Poland - Waiting for Immigrants. But Do We Really Want Them? W: Ricerca condotta nell'ambito del progetto: Politiche migratorie e modelli di societa. Pozyskano z: http://www.cespi.it/WPMIG/Country\%20mig-POLAND.pdf

Dariusz Nowotnik, mgr, Uniwersytet Pedagogiczny w Krakowie, Instytut Geografii.

Absolwent Uniwersytetu Pedagogicznego im Komisji Edukacji Narodowej na kierunkach: geografia z przedsiębiorczością i gospodarką przestrzenną (studia magisterskie, 2008-2010) oraz Geografia z przyrodą (studia licencjackie, 2005-2008). Obecnie doktorant na II roku na wymienionej uczelni na kierunku geografia społeczno-ekonomiczna, korepetytor w firmie Platu Korepetycje oraz zastępca sekretarza w czasopiśmie Annales Universitatis Paedagogicae Cracoviensis. Studia Geographica. Jego główne zainteresowania naukowe to migracje wewnętrzne i zagraniczne, urbanistyka i rozwój obszarów podmiejskich w polskich miastach.

Dariusz Nowotnik, graduate of the Pedagogical University of Cracow, studied Geography with Entrepreneurship and Land Management (postgraduate studies, 2008-2010) and Geography and Nature 
(undergraduate studies, 2005-2008). Currently a PhD student in his second year at the aforementioned university, studying Social-Economic Geography, a teacher at the company Platu Korepetycje and deputy secretary in the journal Annales Universitatis Paedagogicae Cracoviensis Studia Geographica. His main academic interests are internal and international migration, urban planning and development of suburban areas in Polish cities.

adres/address: Uniwersytet Pedagogiczny w Krakowie,

Instytut Geografii, ul. Podchorążych 2,

30-084 Kraków, Polska

e-mail: d.nowotnik@interia.pl 